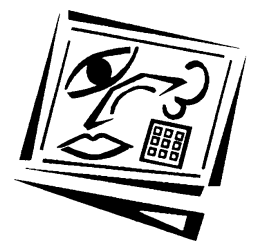

\title{
Using a problem based, multimedia enhanced approach in learning about teaching
}

\author{
Susan E. Gibson \\ University of Alberta \\ Many teachers graduate from teacher education institutions with minimal \\ understanding about how to use technology in their classrooms. This is \\ due mainly to the limited exposure they receive to innovative uses for \\ technology in their preservice programs. There is a need for more \\ information on what new ways of teaching using computers by education \\ faculty might look like. Faculty sharing of stories about their own \\ innovative attempts to integrate technology can be powerful catalysts for \\ others. This article describes the use of a WebCT based virtual field trip to \\ a school used as part of a social studies curriculum and instruction course, \\ designed to help preservice teachers to "rethink" traditional instruction.
}

\section{Introduction}

Until recently, social studies education has been dominated by and hindered by the prominence of knowledge transmission (Cuban, 1993; Diem, 2000; Engle, 1996; Schimmel, 1997; White, 1997). Sewell and Brown (1999) claim that "quality social studies learning is about active learning, asking questions, collecting and analysing information, exploring values, drawing conclusions, communicating, applying and reflecting new knowledge, and making decisions about possible social action" (p. 21). In order to learn to be teachers who have this vision for their future social studies programs, preservice teachers need to be engaged in experiences that help them to rethink traditional teacher centred, didactic instruction (Crocco, 2001). The challenge for teacher educators is to design courses that will encourage inquiry into alternate ways of envisioning social studies teaching and learning (Barron \& Goldman, 1994).

A possibility for encouraging exploration of alternative approaches to teaching is through the use of computer technologies in teacher education courses (Albion \& Gibson, 1998). According to Duffy and Jonassen (1992), preservice teachers can particularly benefit from 
opportunities to examine ways that technology can be used to support a more student centered, inquiry oriented approach to teaching social studies. Wiburg (1991) claims further that integrating technology in teacher education programs is also important in order that preservice teachers learn about the importance of developing and using computer based lessons in their own teaching.

Although some university professors are beginning to use technology in their teaching, it is occurring slowly (Barron \& Goldman, 1994; Maddux, Johnson \& Harlow, 1995; Marx, 1995). Albion and Gibson (1998) maintain that individual faculty sharing innovative teaching methods can encourage others as "examples of effective practice with technologies may assist teachers to acquire the insights which will enable them to adapt their own practice" (p. 1). In this article, I share both my students' and my own personal experiences with integrating inquiry about social studies and about the use of computer technologies into my preservice social studies curriculum and instruction course. By modelling an inquiry approach to my course that engages students in investigating open ended questions about teaching social studies, and by supporting their learning with a web based virtual field trip, my goal was to encourage my students to investigate problems of practice while at the same time thinking about alternative ways of teaching and of integrating technology.

\section{Why constructivist theory as a framework?}

According to White (1999), “Technology can provide opportunities to make social studies education empowering and transformative, but meaningful, student centered, constructivist approaches are vital" (p. 4). Such approaches "encourage students to develop problem solving and critical thinking skills and to apply, analyse, synthesise, and evaluate knowledge, skills, and attitudes" (White, 1999, p. 2). To better prepare our future teachers to use these approaches, White advocates modelling a constructivist, student centered orientation in teacher education.

Constructivism is a learning theory that is guided by a number of principles. Learning is viewed as an active and social process in which the learner constructs new knowledge rather than acquiring information, and instruction is viewed as a process of supporting that construction, rather than communicating knowledge (Brooks \& Brooks, 1993). The new learning builds on previously stored knowledge, and as the learner elaborates upon and interprets the information, initial ideas are reshaped (Fosnot, 1992). Learning occurs most effectively when it is situated in 
experiences that are authentic and meaningful to the learner (Duffy \& Cunningham , 1996). Activities need to promote inquiry through the use of the learner's background knowledge and ongoing learning experiences, and engage the learner in creatively applying the new information. White (1997) advocates using such a constructivist, student centered orientation to teacher education to better prepare our future teachers to use approaches that "encourage [their] students to develop problem solving and critical thinking skills and to apply, analyse, synthesise and evaluate knowledge, skills and attitudes" (p. 2).

One instructional model that exemplifies constructivist learning principles is problem based learning (Duffy \& Cunningham, 1996). Dimock and Boethel (1999) state that, "Learning environments that most effectively support student learning are ones where teachers organise instruction around learning problems that pique students' interest, challenge their current understandings, set the intended concepts in meaningful contexts and allow students to explore ideas, pose interpretations or hypotheses, test their ideas, apply them in other contexts and reflect on their learning" (p. 15). One of the main characteristics of problem based learning is situating the learning in the examination of authentic, real life problems and questions of relevance to the learner, in order to engage them in the learning. Computer technologies can be effective vehicles for introducing problems for student investigation, because they "allow students to experience a shared context in which they engage in sustained thinking about complex problems and engage in interpretive learning experiences (Barron \& Goldman, 1994). In this way, problem based learning could be used at the preservice level to heighten students' appreciation of the realities of teaching practice (Albion \& Gibson, 1998). Organising course content around significant questions or problems can also assist students in developing higher order thinking skills (Ephratt, 1995).

\section{How was the Virtual Field Trip designed?}

I teach an undergraduate curriculum and instruction course in social studies in a large teacher education program. In the past, as a part of this course, I have arranged visits to schools for my students so they could be immersed with teachers and children in their classrooms as they experienced social studies. However, these visits became increasingly more complicated to arrange due to inflexibility in my students' programs. My initial interest in using computers in my teaching came from a desire to try to virtually replicate some form of this school based 
experience. I created a virtual field trip to an elementary school using WebCT. The virtual school was modelled after an actual school in a local school district.

Drawing on the literature about constructivism and problem based learning, I chose to organise the virtual field trip around five key questions related to teaching and learning social studies that my students could investigate. These questions originated from a group of my students during a brainstorm activity at the beginning of the course. The questions selected were:

- Why is social studies taught in elementary schools?

- How do you choose content and plan for instruction in social studies?

- What resources are available to support your teaching of social studies?

- What approaches to social studies teaching would best help you to meet your goals?

- How do you assess children in order to enhance their learning in social studies?

Since I wanted to engage my students in the process of thinking through these important teaching questions using actual classroom practice examples, the virtual field trip provided a variety of multimedia experiences as well as weblinks for my students to examine.

\section{Getting acquainted with the virtual school}

On the homepage, students are introduced to the school that is to be the site of their virtual experiences throughout the course.

Here, by clicking on School Tour, my students could take a visual tour of the school building, listen to a welcome message from the principal, view samples of teachers' weekly timetables and examine a copy of the school handbook. The website also provided opportunities for my students to view the course outline online under Attention Student Teachers and to examine a variety of professional development websites related to social studies under Professional Development Opportunities. By clicking on Student of the Week, students can create their own webpages about themselves as a way of getting better acquainted with their classmates. The Learning Resource Centre contains a conference forum for discussion, a direct email link to the instructor, a glossary and a calendar of upcoming due dates. The five problems to be investigated are accessed by clicking on Notice: Issues in Social Studies. 


\section{Weleome to Brander Gardens School}

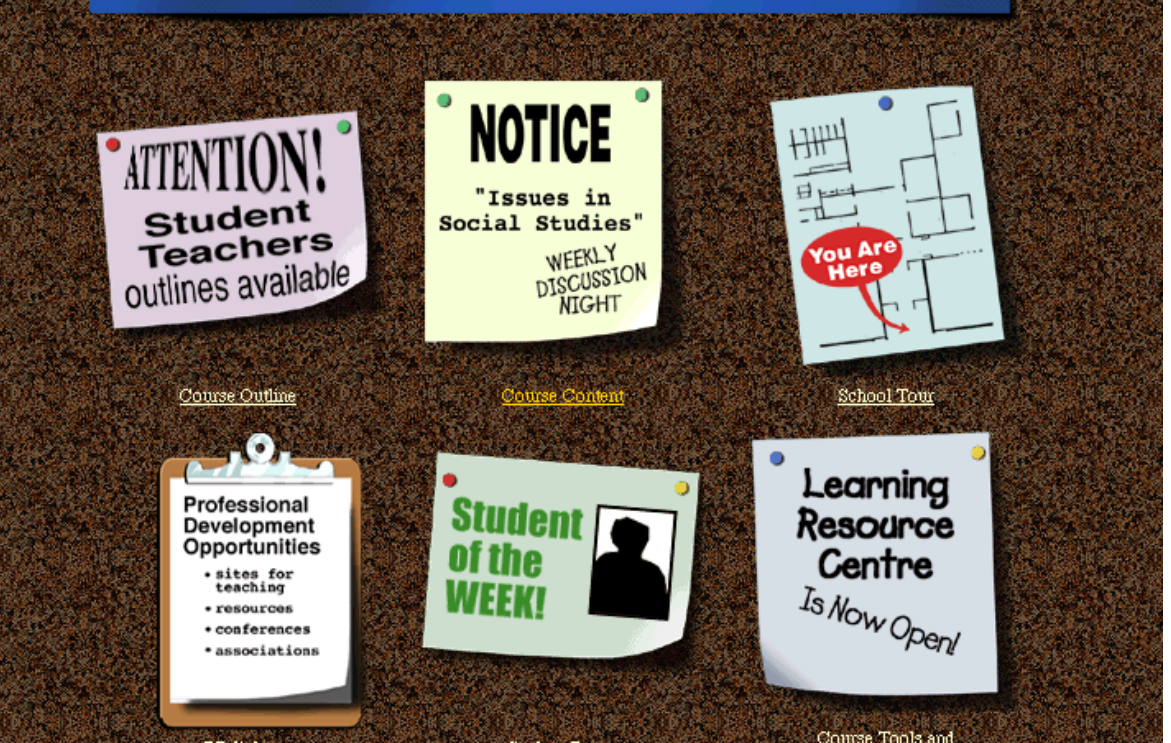

Figure 1: Home page of the WebCT Virtual Field Trip

\section{Investigating the 5 problems about teaching and learning social studies}

Beginning with the first problem, my students conducted a two week investigation of why social studies is taught in elementary schools from five different perspectives - those of teachers, children, curriculum, experts and peers. Students were able to listen to audioclips of interviews held with several teachers and student teachers (peer lens) at the school in which they talked about their beliefs regarding the importance of social studies as a school subject and the role of citizenship education in social studies. My students could also view videoclips of those same teachers and student teachers working with children in the classroom on social studies lessons related to the children's views on citizenship and social studies. Copies of sample lesson plans and work generated by the children in these lessons including a brainstorm list of what it means to be a good citizen and how citizenship is connected to social studies were also provided online. As well, my students then could listen to audioclips of interviews with individual children at various grade levels in the school regarding what they believed social studies was all about. 
Students were also provided access to a variety of curriculum documents from across the country to examine the differing views of social studies articulated in those documents. Finally students were able to read responses to the question of why social studies is an important subject written by experts from four different universities. A sampler of the course website can be viewed at:

http: / / www.atl.ualberta.ca/project/ hatsoff.cfm

under Faculty of Education - Instruction in Elementary Social Studies. Click on Course Content on the virtual field trip homepage to examine Problem 1.

\section{How the course was organised}

Two weeks of the 13-week course were spent examining this first problem. We had one face to face seminar and one class in a computer lab each week. Students selected, collected and synthesised the information presented through all five lenses on the virtual field trip and in the reading materials provided for the first problem based on what they felt best helped them to better understand the problem. After examining the problem in the lab using the virtual field trip, my students and I shared and discussed their findings in small group and large group sessions in the weekly seminar.

Since I concurred with Crocco (2001) that preservice teachers benefit from having opportunities to clarify their own personal vision for their teaching, by reflecting about and building on their prior knowledge and previous understandings, I then asked students to write a reflective synthesis paper in which they discussed their learning about the problem of why social studies is taught in schools, based on their web and seminar experiences at the end of the two week period. I was particularly interested in how their thinking may have changed as a result of those experiences, what it was that caused the change and what this new information means for their future teaching of social studies. We then moved to the next problem and repeated the pattern until we have completed all of the five problems.

\section{How did using the Virtual Field Trip help students to learn about teaching?}

In the fall of 2000, a graduate research assistant was hired to administer a questionnaire (see Appendix A) to all students in the course $(n=18)$ and to interview self selected students $(n=6)$. These interviewees volunteered 
by responding to a question at the bottom of the questionnaire form that asked if they would be willing to be interviewed. All those who indicated willingness were interviewed. The findings from the questionnaire and the interviews have been organised under three headings: learning about how to teach social studies, learning about using technology in the teaching of social studies and the virtual field trip as a tool for supporting preservice students' learning.

\section{Learning about how to teach social studies}

Overall student responses indicated that they felt they gained many new insights and ideas about how to teach social studies as a result of their course experiences. The responses to the question "How comfortable do you currently feel towards teaching social studies curricula?" are indicated below on both initial and summative questionnaires.

Table 1: Growth and/ or change in students' thinking about teaching and learning social studies

\begin{tabular}{|l|c|c|}
\hline $\begin{array}{l}\text { How comfortable do you } \\
\text { currently feel towards teaching } \\
\text { social studies curricula? }\end{array}$ & $\begin{array}{c}\text { Initial } \\
\text { Questionnaire } \\
\mathrm{N}=18\end{array}$ & $\begin{array}{c}\text { Summative } \\
\text { Questionnaire } \\
\mathrm{N}=18\end{array}$ \\
\hline Very Comfortable & 1 & 10 \\
\hline Comfortable & 3 & 5 \\
\hline Somewhat Comfortable & 9 & 3 \\
\hline Slightly Comfortable & 3 & 0 \\
\hline Not Comfortable & 2 & 0 \\
\hline
\end{tabular}

On the open ended comments section of the summative survey questionnaires, students stated, "I have a better understanding of the subject," I learned new methods of teaching and lesson planning ideas," and "I'm more comfortable about teaching social studies with more tools and more confidence." In one interview, a student commented about her growth in her ability to choose a variety of teaching strategies and to rethink traditional teaching practice:

It [the course] built my confidence to teach social studies in a variety of ways and about how you would go about teaching the material in sort of new ways, in interesting ways, rather than just standing there and blabbing, or just using those old atlases and stuff. It gave you different kinds of examples of how different things would work. Like I did a learning center for my project and there was an example with a Grade 6 class studying government on the virtual field trip. They [the teachers] had examples of how they did it on task cards, so I think both the text and our lectures and some of the lenses [provided on the virtual field trip] sort of focused me on how you would go about doing that and what components are necessary, so it was something I wanted to try and I did it and now I know how to do that with future classes. 
A second area related to teaching and learning social studies noted in the interviews was an increase in understanding of constructivism:

I've gone to the constructivist approach of hands on work, relinquishing my control to the students, and letting them show me that they're able to produce work that they're chosen to do rather than me telling them what I want done. It allows them to choose what they want, and then hopefully the learning will come from their interests. It's definitely more sort of higher level critical thinking. I would like that type of strategy rather than just a textbook kind of reproduction.

\section{Learning about using technology in the teaching of social studies}

Students also talked about their growth in skill and understanding of how to integrate computers into social studies teaching. On the questionnaire, the majority of students stated that they were generally more positive, comfortable and knowledgeable about using computers as tools in their future social studies classrooms (see Table 2). They also noted that they grew to understand that using computers could positively influence the teaching and learning of social studies.

Table 2: Growth and/or change in students' thinking about computers and their use as teaching and learning tools in social studies

\begin{tabular}{|l|c|c|}
\hline $\begin{array}{l}\text { How comfortable do you currently } \\
\text { feel about using a computer? }\end{array}$ & $\begin{array}{c}\text { Initial } \\
\text { Questionnaire N=18 }\end{array}$ & $\begin{array}{c}\text { Summative } \\
\text { Questionnaire N=18 }\end{array}$ \\
\hline Very Comfortable & 2 & 5 \\
\hline Comfortable & 3 & 9 \\
\hline Somewhat Comfortable & 4 & 3 \\
\hline Slightly Comfortable & 5 & 1 \\
\hline Not Comfortable & 4 & 0 \\
\hline
\end{tabular}

Through the course experiences, students saw the possibilities for "personal learning," "increasing interactions," "sharing, "interactivity" and "being a part of the global neighborhood" that the Internet provides. One student who was interviewed commented about his growth in his searching skills:

I've worked with the Internet for a long time, but there's stuff that you don't go over. You don't really start from any kind of fundamental level; you just jump in, especially us older people... like I was saying before, the general searches and knowing how to sift through a lot of the stuff that isn't so good on the web. There's so much teaching material there. There's ready made lesson plans all over the place; it's just a matter of knowing what's quality. 


\section{The virtual field trip as a tool for supporting preservice teachers' learning}

Students also commented on the aspects of the course that they felt helped to enhance their learning the most. Overall, the students felt that they were engaged in a meaningful, authentic and relevant learning experience through the use of the problem based approach to the course content and the setting of the course within a real school context. The multiple perspectives were especially helpful for helping students to gain insights about teaching and children and to pick up assessment, resource and organisational ideas. One student who was interviewed felt that he grew the most in terms of his understanding of how important it would be to consider different perspectives on the problems and issues that he might confront in his own teaching.

While still maintaining my own sort of perspective on the problem, I think I was able to be a little more objective about it and stand back and look at it as if I was justifying it to an administrator or a parent or the kids themselves. And I think before the course I would have just gone ahead with exactly what I wanted to do and maybe consulted the curriculum, but not taking into consideration any of the larger issues.

Regarding the five different lenses that the students were given to view each problem through, the majority rated the experiences of listening to and watching teachers as most interesting and informative. Some of the responses on the questionnaire included: "It was great to hear from experienced teachers as they provided good insight," "This lens helped me to understand the issues because the teachers have been there," and "I learned some really useful information such as year plans and lesson plans." One student who was interviewed claimed that it was particularly beneficial for her to see the teachers trying out their planned activities and then hearing the children react to them:

The interviews with the teachers on the web site are most useful in helping me to become a social studies teacher. Just listening to some of the teachers talk and seeing them in action, and then hearing what the kids like and their opinions on what the teachers are doing is good. Those are probably the most helpful, and seeing how the teachers especially what approaches they're taking other than just the transmission sort of ideas...The teachers often give examples of lesson plans and how they go about sort of the theory of why they're doing it, and then they give you an example of how they're doing it. They take it to the class and show kids in action, so it's useful to see how they're using them. And just seeing how kids are different, it makes you think that maybe not everyone is going to like the one approach I want to do, so that's good. 
The second most informative lens according to the responses on the questionnaire was the peer lens. The students responded on the questionnaire that they felt that they could relate easily to what their peers were experiencing and that "It was good to hear from people our own age that they have the same concerns that I do." One person interviewed also noted that he learned from listening to and watching his peers in action because they were closer to his level of experience.

I do find the peer stuff to be quite useful. And you can just see, really, that they've just recently come out of school, and you can notice that some of the rhetoric is still there, but then they're starting to discover what works practically in the classroom; whereas the more experienced teachers, I don't know, they've made a bit of a leap, so you can take it into account, but it just doesn't apply as readily.

Students responded on the questionnaire that hearing the children's ideas and points of view was also helpful in clarifying their understanding of teaching social studies.

In addition to learning from the various lenses provided, students also commented on the helpfulness of the problem based learning approach. In her interview, one student commented that this approach to the course content was useful for her because it made it easier to see the connections between each part of the course and it helped her to stay organised and focused.

I was just thinking how it's [the course] so organised with the questions. I think that's actually really good to have it that way. I think that worked because it sort of kept you focused and everything sort of leads into each other. It was all very much connected. I think it sort of illustrated all the points that she [the instructor] was trying to make. She had broken it down into the different five units and then there were concrete examples of how they would actually work, which was good.

Another interviewee liked the combination of the theoretical and the practical that the weekly lab/seminar format afforded because she felt that the reality of the classroom evident in the lab supported the more theoretical aspects of the seminar.

It's good that I hear about activities in class and then when we go in the lab the next day I see pretty much a lot of the things that I was looking at in class, teachers actually using them. I think it is very beneficial because, unlike a lot of other courses, it has the sort of practical aspect. I just don't like very theoretical courses because then I go talk to my mom, who's a teacher, and she says, "That doesn't work in the real classroom." But she's said that several things that I saw on the virtual field trip were actually working. Normally you go to a course and you get the theory and you think, "That's not going to work; the learning-center idea is not going to 
work. Or the project idea, Fern's [one of the teachers on the virtual field trip] thing, you're not going to get them to build a playground; they're totally not able to do that." And then you actually see it. When you see the footage of the kids actually doing these things, you're like, "Oh! Maybe they can do it." So it changed my opinion on what kids are actually able to do. And then in theory, being actually applied to reality, it did actually work. It wouldn't have been the same if she [the instructor] didn't have that component, I don't think. It would be less believable. So I think that'll be the biggest challenge with the [teacher education] courses, trying to integrate them into real life, because it's a lot of work. But I did see it in the virtual field trip and I know now it is possible to be one of these Wonder Woman teachers.

Through the use of the virtual field trip experiences and the course in general, I was hoping to increase my students' understanding of alternative, less traditional ways of teaching social studies and to enhance understanding of the use of computers for their own teaching. Overall based on the student questionnaire responses and interviews, I would say that the evidence points to growth in their understanding of what teaching social studies entails and what alternative approaches to teaching social studies might look like in the classroom. They also grew in their technological skills from weekly use of the computer and in their understanding about how they might take a similar approach to using computers in their teaching.

\section{What are my recommendations for teacher educators?}

Most beginning teachers have limited knowledge of the ways technology can be used in their professional practice when they graduate from teacher education institutions. And yet, as Kortecamp and Croninger (1995), argue "effectively applying technology is high on the list of what beginning teachers should know and be able to do in today's classroom" (p. 286). The important task for teacher educators is to find ways to use computers as something more than an add on to the ways we have always taught. What preservice teachers need is computer experiences that help them to rethink traditional instruction. Basing computer experiences on constructivist learning principles in one way of assisting students to think differently about both teaching and the role of computers in their classroom. Woodrow (1993) states, "Preservice teachers must perceive computers as integral parts of the instructional strategies and professional activities of teachers and become committed to their use" (p.373).

Technology integration can help preservice teachers to develop new models of teaching and learning. Interactive multimedia based on 
problem based learning principles may be one of the combinations that will contribute to the next wave of improvements in the proportion of future teachers learning with technology. This article has presented one such possibility for helping preservice teachers to "rethink" traditional instruction by immersing them in a constructivist, problem based learning environment with the assistance of the technology. Integrating technology into preservice courses can be a risky business. It is never easy to move away from the tried and true. However, experiences such as the ones shared here demonstrate that change can be very rewarding for both faculty and preservice teachers.

\section{References}

Albion, P. \& Gibson, I. (1998). Designing problem-based learning multimedia for teacher education. Technology and Teacher Education Annual. Virginia: Association for the Advancement of Computing in Education. [URL not found 3 Oct 2002] http:/ / www.coe.uh.edu/insite/elec_pub/HTML1998/th_albi.htm

Barron, L. \& Goldman, E. (1994). Integrating technology with teacher preparation. In B.Means (Ed), Technology and Education Reform (pp. 81-110). San Francisco: Jossey-Bass.

Brooks, J. \& Brooks, M. (1993). In search of understanding: The case for constructivist classrooms. Alexandria, Virginia: Association for Supervision and Curriculum Development.

Crocco, M. (2001). Leveraging constructivist learning in the social studies classroom. Contemporary Issues in Technology and Teacher Education, 1( 3). [verified 3 Oct 2002]

http://www.citejournal.org/vol1/iss3/currentissues/socialstudies/article2.htm

Cuban, L. (1993). How teachers taught. 2nd Edition. New York: Teachers College Press.

Diem, R. (2000). Can it make a difference? Technology and social studies. Theory and Research in Social Education, 28(4), 493-501.

Dimock, K. \& Boethel M. (1999). Constructing knowledge with technology. Southwest Education Development Lab, Austin TX, ED 431398.

Duffy, T. \& Jonassen, D. (1992). Constructivism: New implications for instructional technology. In T. Duffy \& D. Jonassen (Eds), Constructivism and the technology of instruction: A conversation (pp. 1-16). Hillsdale, NJ: Lawrence Erlbaum.

Duffy, T. \& Cunningham, D. (1996). Constructivism: Implications for the design and delivery of instruction. In D. Jonassen (E.), Handbook of Research for Educational Communications and Technology (pp. 170 - 198). New York: Simon \& Schuster Macmillan. 
Engle, S. (1996). Foreword. In R. Evans \& D. Saxe (Eds), Handbook on Teaching Social Issues, (pp. v-viii), NCSS Bulletin 93, Washington, DC.

Ephratt, M. (1995). The computer in teacher education - a tool or a partner? In R. Hoz \& M. Silberstein (Eds), Partnerships of schools and institutions of higher education in teacher development (pp. 103-120), Ben-Gurion University of the Negev Press.

Fosnot, C. (1992). Constructing constructivism. In T. Duffy \& D. Jonassen (Eds), Constructivism and the technology of instruction: A conversation (pp. 167 - 176). Hillsdale, NJ: Lawrence Erlbaum Associates.

Howard, D. C. \& Howard, P. A. (1993). Learning technology: Implications for practice. Technology and Teacher Education Annual. (pp. 389-394). Virginia: Association for the Advancement of Computing in Education.

Kortecamp, K. \& Croninger, W. (1995). Integrating technology in preservice education: a model for faculty development. Technology and Teacher Education Annual. (pp. 283-286). Virginia: Association for the Advancement of Computing in Education.

Maddux, C. \& Johnson, L. \& Harlow, S. (1995). Teacher education and the Internet: Where do we go from here? Technology and Teacher Education Annual. (pp. 581-584). Virginia: Association for the Advancement of Computing in Education.

Marx, S. (1995). Toss the text: integrating telecommunications in social studies teacher education. Technology and Teacher Education Annual. (pp. 78-82). Virginia: Association for the Advancement of Computing in Education.

Schimmel, D. (1997). Traditional rule-making and the subversion of citizenship education. Social Education, 6(12), 70-74.

Sewell, A. \& Brown, M. (1999). Computer technology and citizenship education: A social partnership. The New Zealand Journal of Social Studies, 8(2), 20-26.

White, C. (1997). Preservice to the "real world": Transforming social studies through technology. Technology and Teacher Education Annual Virginia: Association for the Advancement of Computing in Education.[URL not found 3 Oct 2002] http:/ / www.coe.uh.edu/insite/elec_pub/HTML1997/ss_whit.htm

White, C. (1999). It's not just another new thing: Technology as a transformative innovation for social studies teacher education. Journal of Technology and Teacher Education, 7(1), 3-12.

Wiburg, K. (1991). Teaching teachers about technology. Computers in the Schools, $8(1 / 2 / 3), 115-129$.

Woodrow, J. (1993). The implementation of computer technology in preservice teaching. Technology and Teacher Education Annual. (pp. 368-373). VA: Association for the Advancement of Computing in Education. 


\section{Appendix A}

\section{EDEL 435 Initial and Summative Survey}

This survey is designed to provide us with information regarding course content and the pilot evaluation for the virtual field trip component of EDEL 435. The focus of this survey is on computer use and its role in the success of this course. The information collected will be used to make modifications and improvements to the program in the future. All of the information collected will remain completely anonymous. Please do not write your name anywhere on this survey. The survey should take only a few minutes to complete. Use the back of the sheet, should you need additional space.

\section{Part I - Social Studies Course Content}

1. How comfortable do you currently feel towards teaching social studies curricula? (circle one)
a. Very Comfortable
b. Comfortable
c. Somewhat Comfortable
d. Slightly Comfortable
e. Not Comfortable

2. Describe some effective ways for children to learn about social studies:

3. How did you find the workload of the EDEL 435 course? (circle one)

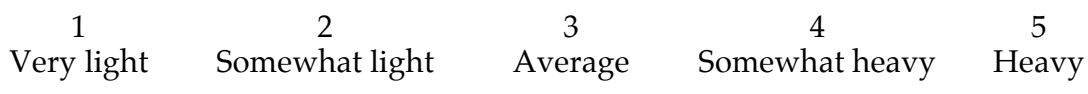

4. How did you find the time period you had to complete the course material? (circle one)
1
23
4
5

Very short Somewhat short Average Somewhat long Long

5. If you were asked to explain to a class of children what social studies is, what would you say?

6. Rate the following out of three from highest (3) to lowest (1) based upon your learning experiences from these components of the course. Please comment why in the space provided:

a. Learnings through the text readings

b. Learnings through the traditional classroom experience

c. Learnings through the virtual field trip computer lab experiences

7. Were your expectations for this course, that was designed to prepare you to teach social studies for the elementary classroom met? Explain. 


\section{Part II - Technology Component}

1. What is your opinion of the Virtual Field Trip for learning and applying concepts and skills? (circle one)
1
3
4
5

$$
2
$$

Not helpful Slightly helpful Somewhat helpful Helpful Very Helpful

2. What are your current feelings towards using the Virtual Field Trip format as a course component? (circle one)

$\begin{array}{ccccc}1 & 2 & 3 & 4 & 5 \\ \begin{array}{c}\text { Prefer } \\ \text { faditional } \\ \text { format }\end{array} & \begin{array}{c}\text { Somewhat } \\ \text { prefer } \\ \text { traditional } \\ \text { format }\end{array} & \begin{array}{c}\text { No } \\ \text { preference }\end{array} & \begin{array}{c}\text { Somewhat } \\ \text { prefer } \\ \text { new format }\end{array} & \begin{array}{c}\text { Prefer new } \\ \text { format }\end{array} \\ & & & & \end{array}$

3. How did you find your experience when getting the necessary help and assistance on using the Virtual Field Trip? (circle one)
1

2
Very easy Easy Somewhat easy Difficult Very difficult
3
4
5

4. How interesting did you find the Virtual Field Trip component? (circle one)
a. Very Interesting
b. Interesting
c. Somewhat Interesting
d. Slightly Interesting
e. Not at all interesting

5. Rate the following lenses from least interesting (1) to most interesting (5) and explain why you chose this in the space provided:

\begin{tabular}{l} 
a. Teacher Lens \\
b. Expert Lens \\
c. Peer Lens \\
\hline$\_$d. Student Lens \\
e. Curricular Lens
\end{tabular}

6. Do you anticipate that the computer skills you have developed in this course would be useful to you in future work or related professional activities? Explain.

7. How comfortable do you currently feel about using a computer? (circle one)
a. Very Comfortable
b. Comfortable
c. Somewhat Comfortable
d. Slightly Comfortable
e. Not Comfortable 
8. Would you consider taking another course for credit this way?
a. Yes
b. No
c. Not Sure

9. Have you had any problems understanding how to use the computer for this course?
a. Yes ....please explain?
b. No

10. How many days during this course would you estimate it took you to learn how to use the Virtual Field Trip program to a level where you felt comfortable?

11. Which option below best describes your preference for using or integrating this type of program within the general curriculum courses in the Elementary Education department?

a. I think it should be widely used with most Elementary Education courses.

b. I think it can be used with parts of some of the courses (where there is justification)

c. I think it should be seldom used in only a few specified courses.

d. I think it should never be used; there are better ways to do the same things.

12. How do you think your attitude has changed towards using the computer with instruction from the beginning of this course to now? (circle one)
a. Much worse
b. Slightly worse
c. Not changed
d. Slightly better
e. Much better

13. Comments or suggestions you would make for improving this course and its delivery methods for future classes?

Susan E. Gibson, Associate Professor

Department of Elementary Education

551 Education South, University of Alberta

Edmonton AB, CANADA T6G 2G5

Phone: (780) 492 4273, ext.233 Fax: (780) 4927622

Email: susan.e.gibson@ualberta.ca 
